\title{
SELECTION OF COFFEE PROGÊNIES FOR RESISTANCE TO LEAF RUST AND FAVORABLE AGRONOMIC TRAITS
}

\author{
Rafael Almeida Dias ${ }^{1}$, Marcelo Resende Ribeiro ${ }^{2}$, Alex Mendonça de Carvalho ${ }^{3}$, \\ Cesar Elias Botelho ${ }^{4}$, Antonio Nazareno Guimarães Mendes ${ }^{5}$, André Dominghetti Ferreira ${ }^{6}$, \\ Fernando Costa Fernandes ${ }^{7}$
}

(Received: March 12, 2019; accepted: May 14, 2019)

\begin{abstract}
ASTRACT: The objective of this study was to select coffee progenies with better assessment that can result in coffee rust resistant cultivars and better agronomic characteristics than the traditional ones. The essay was performed at the EPAMIG experimental field in Patrocínio, state of Minas Gerais, Brazil. Twenty-five progenies in the $\mathrm{F}_{3}$ generation were studied. The experiment was set in a randomized complete block design with three replicates and ten plants per plot, arranged in rows at $3.5 \times 0.7 \mathrm{~m}$. Productivity assessment, fruit production, in liters of "farm coffee" per plot, bean rating in a sieve (16 or above), and plant vigor were accessed in three different harvest seasons (2011/2012 harvest to 2014/2015 harvest), and coffee rust incidence and severity were then evaluated for 2016. The production profit estimation through the selection was also assessed, by the gain of direct selection for each characteristic, when compared to the rank addition. Progenies 13 (Icatu V. IAC $4040 \mathrm{x}$ IAC 5002) and 3 (Icatu A. IAC 2944 x IAC 5002) were promising in generation advance, for being among the five most productive progenies. The selection gain reached by direct selection was superior than the gain of the total rank additions.
\end{abstract}

Index terms: Hemileia vastatrix, Icatu derivatives, Coffea arabica, breeding genetic gain.

\section{SELEÇÃO DE PROGÊNIES DE CAFEEIRO VISANDO CARACTERÍSTICAS AGRONÔMICAS FAVORÁVEIS}

\begin{abstract}
RESUMO: Objetivou-se com o presente trabalho selecionar progênies de cafeeiro visando o avanço de seleção para posterior obtenção de cultivares resistentes a ferrugem do cafeeiro e com características agronômicas superiores às cultivares tradicionais. O experimento foi instalado no campo experimental da EPAMIG em Patrocínio MG, compreendendo 25 progênies em geração $\mathrm{F}_{3}$. O delineamento experimental utilizado foi o de blocos casualizados com três repetições, no espaçamento de $3,5 \mathrm{x} 0,7 \mathrm{~m}$ e parcelas de 10 plantas. As avaliações de produtividade, produção de "café da roça", percentagem de grãos classificados em peneira 16 acima e vigor vegetativo foram efetuadas em quatro colheitas, safras 2011/2012 a 2014/2015 e, posteriormente, foi avaliada a incidência e severidade da ferrugem no ano de 2016. Foram realizadas também estimativas dos ganhos com a seleção, por meio do ganho de seleção direta para cada característica em comparação com a soma de postos. As progênies 13 (Icatu V. IAC 4040 x IAC 5002) e progênie 3 (Icatu A. IAC 2944 x IAC 5002) foram promissoras para o avanço de geração, por estarem entre as cinco progênies mais produtivas. O ganho de seleção obtido com a seleção direta foi superior aos ganhos obtidos pela soma de postos.
\end{abstract}

Termos para indexação: Hemileia vastatrix, derivados de Icatu, Coffea arabica, melhoramento genético.

\section{INTRODUCTION}

Cultivars 'Catuai' and 'Mundo Novo' still represent most of Coffea arabica L. coffee planting in Brazil (CARVALHO et al., 2009; MATIELLO, 2008). However, these genetic materials are susceptible to coffee leaf rust, caused by the fungus Hemileia vastatrix Berk. et $\mathrm{Br}$. (PAIVA et al., 2010; DEL GROSSI et al., 2013). This pathogen is currently the main phytosanitary problem in coffee plantations, causing serious economic losses to coffee producers (MUNIZ et al., 2009).
Icatu genes have been largely used in breeding programs targeting rust resistance. This germplasm shows resistance to rough conditions, it has high vegetation vigour and grain quality (high sieve), superior drink quality and, especially, shows variability to rust resistance from both types, vertical and horizontal (BOTELHO et al., 2010). Besides the agronomic traits mentioned, several author also related rust resistance of Icatu coffee with high yields, high sieve and vegetation vigour (PEREIRA et al., 2013).

\footnotetext{
1,2,5,7Universidade Federal de Lavras/UFLA - Departamento de Agricultura/DAG - Cx. P. 3037-37.200-000 Lavras-MG - rafaell_diass@hotmail.com, marceloresenderibeiro@gmail.com, nazareno.ufla@gmail.com, fernandocf2009@gmail.com

${ }^{3}$ Universidade Estadual Júlio de Mesquita Filho/UNESP - Campus Registro - SP - 11.900-000 - Registro - SP alex.carvalho@unesp.br

${ }^{4}$ Empresa de Pesquisa Agropecuária de Minas Gerais/URESM - Campus UFLA - Cx. P. 176 - 37.200-000 - Lavras - MG cesarbotelho@yahoo.com.br

${ }^{6}$ Embrapa Café - Campus UFLA - Cx. P. 176 - 37.200-000 - Lavras - MG - andre.dominghetti@embrapa.br
}

Coffee Science, Lavras, v. 14, n. 2, p. 173 - 182, apr.jun. 2019 
Coffee breeding studies currently aim at other desirable characteristics, such as high sieve percentage, high plant vigor and, mainly, resistance to the main pathogens that parasitize the coffee tree, besides high yields (MEDINA-FILHO et al., 2008).

It has long been sought to obtain new cultivars with resistance to the pathogen, totally or partially dismissing the application of fungicides. However, the continuous appearance of new physiological pathogen breeds has caused a "break" in the resistance of cultivars used by farmers and, for this reason, a great effort has been made, by genetic breeding, to obtain new cultivars with durable resistance to the disease (Sera et al., 2010; Del Grossi et al., 2013; Shigueoka et al., 2014).

The objective of this study was to evaluate and select coffee progenies in the $\mathrm{F}_{3}$ generation, obtained from crosses between resistant selections of the Icatu group with cultivars of groups 'Catuai', 'Catuaí' x 'Mundo Novo' and 'Acaiá'.

\section{MATERIALS AND METHODS}

The city is located in the coffee region of Cerrado Mineiro, more precisely at Alto Paranaíba, and the experiment is situated in a flat terrain. In this location the average annual rainfall is 1620 $\mathrm{mm}$, and the average temperature is $22^{\circ} \mathrm{C}$.

The progenies used are the result of crosses between cultivars of the Icatu group with 'Catuaí Amarelo' IAC 62 and IAC 17, 'Catuaí Vermelho' IAC 99, 'Rubi', genetic material originated from 'Catuai' backcrosses with 'Mundo Novo', identified as IAC 5002 and IAC 5010, as well as a cross between 'Acaiá' and 'Catuaí Amarelo' IAC 17. They were selected by the genealogical method and are currently in generation $\mathrm{F}_{3}$. Two progenies in advanced generation and promising for resistance to rust (24 and 25) were used as controls, derived from crosses between the Catimor and Icatu groups, which resulted in the obtention of 'Aranãs' (Tabela 1).

The experimental design was in randomized blocks, with three replications and plots with 10 plants; only six central plants were considered as a useful plot. The adopted spacing was of $3.5 \mathrm{~m}$ between rows $\mathrm{x} 0.70 \mathrm{~m}$ between plants.

The following agronomic characteristics were evaluated in the first four harvests $(2011 / 2012$ to $2014 / 2015$ ): production in liters of "bica corrida" coffee, considering an average yield of 480 liters of "farm coffee" for each 60-kg bag of processed coffee (CARVALHO et al., 2009). After coffee processing, a 300-g sample was passed through a set of sieves (17/64 to 19/64), and the material was retained in each sieve, determining the percentage of mocha grains (BRASIL, 2003); plant vigor, evaluated by assigning scores according to an arbitrary 10-point scale, with score 1 given to the worst plants, with very reduced plant vigor and marked degradation symptoms, and score 10 to plants with excellent vigor, more enveiled and with marked plant growth of productive branches, as suggested by Carvalho et al. (1979) and rust incidence and severity. An evaluation was made in 2016, prior to harvest, by collecting 10 leaves per plant of the third or fourth pair of leaves, five of each side in the middle third of the plant. The incidence in percentage was estimated by the number of leaves with rust symptoms, divided by the total number of collected leaves. Severity was assessed according to a scale of 1 to 5 scores, adapted by Petek et al. (2006) where, 1: absence of pustules or hypersensitivity reactions; 2: few leaves with pustules without spores and with hypersensitivity reactions; 3: few pustules per leaf with high production of spores and little distribution; 4: average amount of pustules per leaf, distributed in the plant with high production of spores; 5: High amount of pustules with high production of spores and high defoliation.

For the characteristics yield, vigor, percentage of sieve (17/64 to 19/64)), sievew 10 and bottom, we analyzed the means of the first four harvests, that is, harvests 2011/2012 to 2014/2015. A linear mixed model was used and progeny was considered a random factor. The genetic values BLUP (best linear unbiased prediction) or mixed models were estimated. Genetic gains were also estimated in relation to the general mean or the control with the highest mean. For incidence and severity, the mixed model was not used, since there was no matrix convergence, caused by the high standard deviation values of progenies between replicates. This probably explains the inhomogeneity in the rust pressure between replicates.

The PROC MIXED procedure of the SASStatistical Analysis System program was used, as it is suitable for the analysis of unbalanced mixed models, since it clearly distinguishes between fixed and random effects. This procedure used to adjust mixed linear models allows a general specification of the variance and covariance matrix and adjusts the mixed model using the generalized least squares method. 
TABELA 1 - Progênies de Coffea arabica L. avaliadas em Patrocínio MG.

\begin{tabular}{|c|c|c|}
\hline $\begin{array}{l}\text { Número do } \\
\text { Tratamento }\end{array}$ & Progênie & Genitores \\
\hline 1 & 145-17 Pl. 5 Vermelho & Icatu Vermelho IAC 4042 x Catuaí Amarelo IAC 17 \\
\hline 2 & 143-28 Pl. 6 Amarelo & Icatu Amarelo IAC 2944 x IAC 5002 \\
\hline 3 & 143-29 Pl. 6 Amarelo & Icatu A.marelo IAC 2944 x IAC 5002 \\
\hline 4 & 141-27 Pl. 10 Amarelo & Icatu Amarelo IAC 2944 x Catuaí Amarelo IAC 62 \\
\hline 5 & 140-15 Pl. 8 Amarelo & Icatu Vermelho IAC 4042 x Catuaí Amarelo IAC 62 \\
\hline 6 & 107-15 Pl. 9 Vermelho & Icatu Vermelho IAC 4040 x IAC 5002 \\
\hline 7 & 140-03 Pl.1 Vermelho & Icatu Vermelho IAC 4042 x Catuaí Amarelo IAC 62 \\
\hline 8 & 138-07 Pl. 9 Vermelho & Icatu Vermelho IAC 4040 x Rubi \\
\hline 9 & 130-47 Pl. 6 Vermelho & Icatu Vermelho IAC 2942 x IAC 5002 \\
\hline 10 & 130-24 Pl. 1 Vermelho & Icatu Vermelho IAC 2942 x IAC 5002 \\
\hline 11 & CIV4427 Pl.2 Vermelho & Icatu x Catuaí Vermelho IAC 99 \\
\hline 12 & 132-06 Pl. 2 Amarelo & Acaiá x Catuaí Amarelo IAC 17 \\
\hline 13 & 107-47 Pl. 3 Amarelo & Icatu Vermelho IAC 4040 x IAC 5002 \\
\hline 14 & 130-41 Pl. 7 Vermelho & Icatu Vermelho IAC 2942 x IAC 5002 \\
\hline 15 & 131-06 Pl. 3 Vermelho & Icatu Vermelho IAC 4040 x Catuaí Amarelo IAC 17 \\
\hline 16 & 129-01 Pl. 5 Amarelo & Icatu Vermelho IAC 4042 x Rubi \\
\hline 17 & 133-15 Pl. 3 Amarelo & Icatu Amarelo IAC 2944 x Catuaí Vermelho IAC 99 \\
\hline 18 & 133-15 Pl. 7 Vermelho & Icatu Amarelo IAC 2944 x Catuaí Vermelho IAC 99 \\
\hline 19 & 114-35 Pl. 10 Vermelho & Icatu Vermelho IAC 4242 x Catuaí Vermelho IAC 99 \\
\hline 20 & CIV1511 P1.2 & Icatu x Catuaí Vermelho IAC 99 \\
\hline 21 & 108-43 Pl. 4 Vermelho & Icatu Vermelho IAC 4042 x IAC 5002 \\
\hline 22 & 110-43 Pl. 5 Vermelho & Icatu Vermelho IAC 4040 x Catuaí Amarelo IAC 62 \\
\hline 23 & 113-55 Pl. 2 Vermelho & Icatu Vermelho IAC 4040 x Catuaí Vermelho IAC 99 \\
\hline 24 & $32-3-15-20$ & (Icatu x Catimor)* \\
\hline 25 & $29-1-8-5$ & (Icatu x Catimor)* \\
\hline
\end{tabular}

*Progênies utilizadas como testemunha

For rust incidence and severity, analyses of variance were performed, adopting 5\% significance for the F test. The 'Sisvar' software developed by Ferreira (2008) was used. When significant differences were detected, the means were grouped by the Scott-Knott test, at 5\% probability.

The selection indices used were the direct selection index, which compares the mean of each treatment with the general mean of the experiment, or the average of the best control, and the Mulamba-Mock index (1978), which adds all rankings of each genetic material related to the aimed single traits in a favourable order of improvement, resulting in a selection index, described as follows: $\mathrm{I}=\mathrm{r} 1+\mathrm{r} 2+\ldots+\mathrm{rn}$, being I the value of the index for a given individual or family; rj being the class (or rank) of an individual in relation to the $\mathrm{j}^{\text {st }}$ trait; and $\mathrm{n}$ being the number of traits considered by the index. Adicionally, the variables are specified for diferente wheights, as in $\mathrm{I}=\mathrm{p} 1 \mathrm{r} 1+\mathrm{p} 2 \mathrm{r} 2+\ldots+$ pnrn, where $\mathrm{pj}$ is the economic weight set to the $\mathrm{j}^{\text {st }}$ trait (SANTOS et al., 2007). It is also known as the rank sum index, obtained after the ordering of genetic gains for each genotype as to the character evaluated in the desired direction, and subsequent sum of its rankings, resulting in an additional mean taken as a selection index. For the calculation of index I, the following variables were used: yield, vigor, percentage of sieve $(17 / 64$ to $19 / 64)$ e sievew 10 and bottom. 


\section{RESULTS AND DISCUSSION}

For presentation and discussion of characteristics evaluated in this study, genotypic values that are the result of the sum of the genotypic effects of each progeny with the global average were considered. Around $60 \%$ of the progenies had yields above the global average of the experiment, which was 33.48 bags ha $^{-1}$; this yield average was considered satisfactory, since it was a coffee crop under dry conditions (Table 2 ). In selection studies of progenies derived from crossing in which one of the parents belongs to the Icatu group, values similar to those of this study for average yield were found by Petek et al. (2006).

About $40 \%$ of progenies were highlighted, as they presented yield genotypic values above average of best control (progeny 24, "Icatu" x "Catimor"), which was 33.62 bags ha-1. It is important to emphasize that this is a genetic material knowingly productive, and it was possible to detect a positive gain with the selection, in the case 5.3 bags ha $^{-1}$, considering the first four harvests.

Botelho et al. (2010) worked with progenies from the Icatu $x$ Catimor cross in the $\mathrm{F}_{4}$ generation, and obtained yields that reached $55.85 \mathrm{bags} \mathrm{ha}^{-1}$ in the average of the first six harvests for this control progeny.

Considering only the yield for the selection and selection index of $20 \%$ of the progenies, that is, the five best scored, progenies $23,9,3,2$, and 13 would be selected, since they achieved the highest yields.

For the characteristic vegetative vigor there was an improvement in the values of the expected gain fact explained by estimate of heritability.

For plant vigor thirteen progenies that had above-average scores of the experiment were highlight, and nine progenies with scores above control 24; the five progenies with the highest plant vigor were 4, 11, 5, 7 and 20 (Table 2).

Similar values for plant vigor were found in a study conducted by Botelho et al. (2010). Hight plant vigor is positively correlated with the adaptation of the cultivar to the environment, reflecting on plants with lower degradation (CARVALHO et al., 2012).

Of the five progenies with the highest plant vigor, three yields were below the average of the experiment, namely, progenies 11, 20 and 7 (Table 2), indicating an unfavorable situation for breeding, considering the selection only by plant vigor.
Only progeny 22 had a plant vigor score below seven, but with a yield above the global average and the controls, indicating an unfavorable condition for selection, had only plant vigor been used as a selection criterion. Carvalho et al. (2012) found plant vigor values ranging from 5.9 to 7.5 for 'Catucaí', 'Obatã', 'Araponga' and 'Paraíso', results very similar to those found in this study.

The ranking by sieves is indicated, since it is a characteristic related to the quality standards of the product (CARVALHO et al., 2009). In general, increased bean size provides greater uniformity of the batch to be processed and directly influences the physical appearance of the product, which is desirable mainly for use in espresso machines (FERREIRA et al., 2013).

Progenies 11 and 12, with a percentage above $30 \%$, are considered appropriate for sieve 17 and above; these values are considered adequate for the coffee market and especially for specialty coffees (FERREIRA et al., 2013). This result can be compared with those found by Laviola et al. (2006), who verified that 'Icatu' had the highest percentage of beans retained in sieve 17 and above, when compared to 'Catuaí' and 'Rubí'. Progeny 11 also had good plant vigor, but lower yield in relation to the global average and control 24 (Table 2).

The good result of progeny 12 for this characteristic is justified, since it is the consequence of the crossing with 'Acaiá', known as a genetic material with a high average sieve (CARVALHO et al., 2009).

Of the 25 progenies evaluated, 13 were above the average of the experiment for percentage of beans retained in sieve 17 and above, four of which are among the most productive, namely, 9, 3, 13 and 1 (Table 2), evidencing an interesting opportunity for progeny selection and generation advance. The worst result in relation to the percentage of beans retained in sieve 17 and above was observed in progeny 15 , which also had a yield below the average of the experiment.

Genotypes with a high percentage of beans in sieve 17 and above are commonly selected by coffee breeders, as they are desired by producers, who aim to serve the most demanding consumer markets. Not only can high sieve values be expressed as an indicative of the good genetic constitution of the coffee trees for this characteristic, but they also may reflect the good nutritional and sanitation conditions of the coffee crop during fruit development (CARVALHO, 2014). 


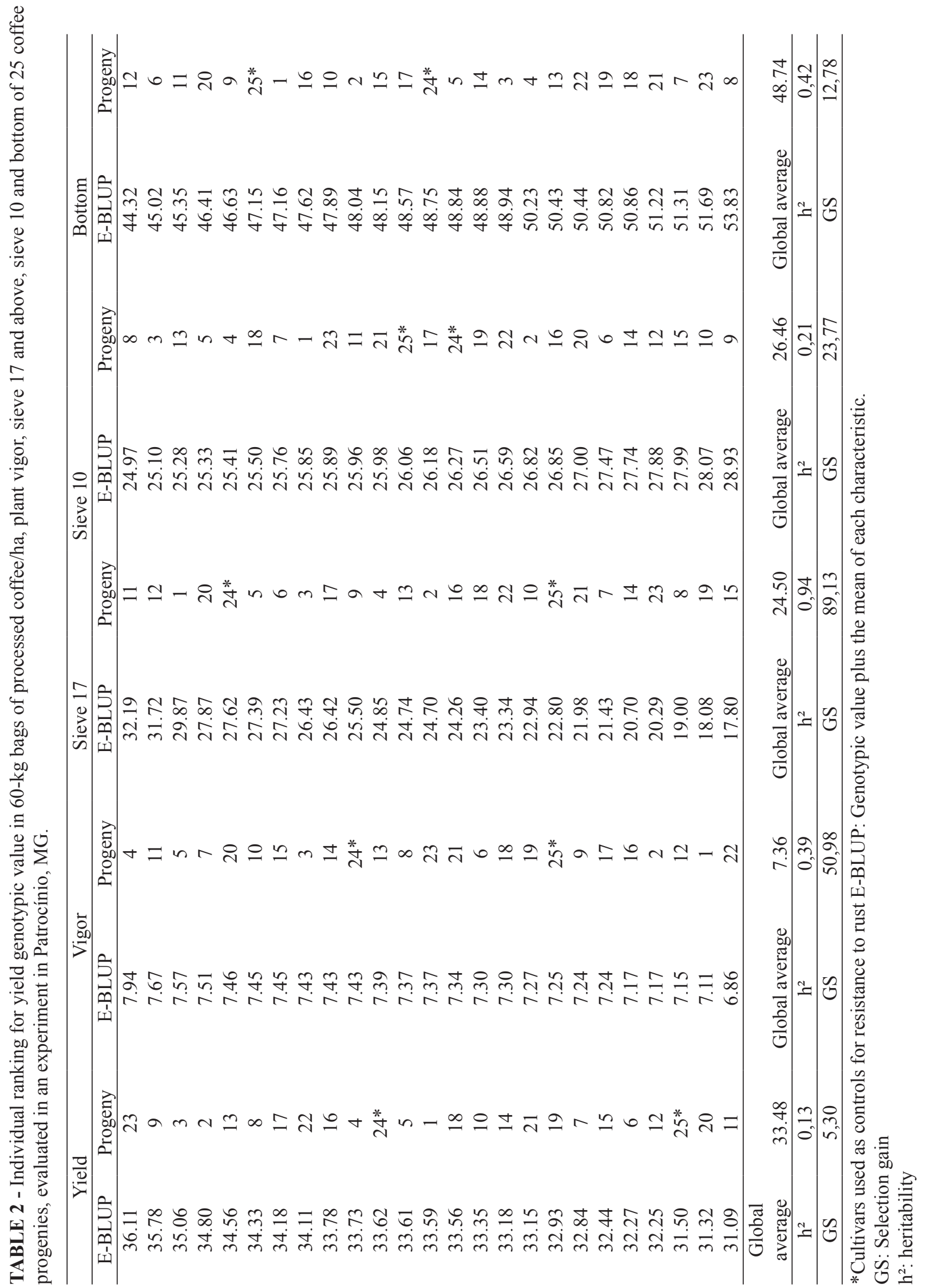


For the variable percentage of sieve 10, 14 progenies with values lower than the average of the experiment were highlighted. Progeny 3 stands out with the second lowest percentage of beans in sieve 10, and was also superior to the global average and control 24 for sieve 17 and above, besides being among the most productive of the experiment. About $44 \%$ of the progenies presented percentage of beans in sieve 10 above the average of the experiment, and the worst result for this variable was observed in progeny 9, with a high percentage, a condition considered unfavorable for selection.

For the variable bottom sieve, 12 progenies showed results below the average of the experiment, but with five progenies that had lower values than control 25 ('Icatu' $\mathrm{X}$ 'Catimor'), which are progenies 12, 6, 11, 20 and 9 (Table 2). Among them, progeny 9 can be highlighted, since it is also among the five most productive, but with a high percentage of sieve 10 .

For rust incidence, three distinct progeny groups of higher and lower incidence were formed. About $76 \%$ of the progenies were in the group with the lowest incidence of the pathogen, which was expected, considering that selections from the 'Icatu' group participated in the crossing to obtain almost all the progenies evaluated. In this superior group, progenies 13 and 3 (Table 3), which were also among the five best for yield and among the five best by the rank addition, are worth highlighting, with averages of 8.33 and $13.33 \%$ for incidence of the disease. Botelho et al. (2010), working with progenies from crosses between 'Icatu' and 'Catimor', obtained similar averages for pathogen incidence in the best progenies studied.

TABLE 3 - Average rust incidence and severity (\%) for coffee progenies in an experiment in Patrocínio, MG.

\begin{tabular}{ccc}
\hline Progeny & Rust incidence (\%) & Rust severity (\%) \\
\hline 19 & $5.0 \mathrm{a}$ & $1.7 \mathrm{a}$ \\
7 & $6.7 \mathrm{a}$ & $1.0 \mathrm{a}$ \\
15 & $6.7 \mathrm{a}$ & $1.0 \mathrm{a}$ \\
21 & $6.7 \mathrm{a}$ & $1.7 \mathrm{a}$ \\
8 & $8.3 \mathrm{a}$ & $1.7 \mathrm{a}$ \\
13 & $8.3 \mathrm{a}$ & $1.7 \mathrm{a}$ \\
25 & $10.0 \mathrm{a}$ & $1.0 \mathrm{a}$ \\
11 & $10.0 \mathrm{a}$ & $1.0 \mathrm{a}$ \\
14 & $10.0 \mathrm{a}$ & $2.3 \mathrm{~b}$ \\
24 & $11.7 \mathrm{a}$ & $2.0 \mathrm{~b}$ \\
6 & $11.7 \mathrm{a}$ & $1.0 \mathrm{a}$ \\
18 & $13.3 \mathrm{a}$ & $2.3 \mathrm{~b}$ \\
3 & $13.3 \mathrm{a}$ & $2.3 \mathrm{~b}$ \\
23 & $15.0 \mathrm{a}$ & $2.0 \mathrm{~b}$ \\
20 & $15.0 \mathrm{a}$ & $1.3 \mathrm{a}$ \\
2 & $16.7 \mathrm{a}$ & $2.7 \mathrm{~b}$ \\
1 & $16.7 \mathrm{a}$ & $1.3 \mathrm{a}$ \\
5 & $18.3 \mathrm{a}$ & $3.0 \mathrm{~b}$ \\
17 & $18.3 \mathrm{a}$ & $2.7 \mathrm{~b}$ \\
9 & $23.3 \mathrm{~b}$ & $2.7 \mathrm{~b}$ \\
4 & $25.0 \mathrm{~b}$ & $2.3 \mathrm{~b}$ \\
16 & $26.7 \mathrm{~b}$ & $3.3 \mathrm{~b}$ \\
22 & $30.0 \mathrm{~b}$ & $2.7 \mathrm{~b}$ \\
12 & $38.3 \mathrm{~b}$ & $3.3 \mathrm{~b}$ \\
10 & $55.0 \mathrm{c}$ & $3.7 \mathrm{~b}$ \\
\hline
\end{tabular}

Means followed by the same letter belong to the same group by the Scott Knott test at $5 \%$ probability. 
In the intermediate disease incidence group are five progenies, namely, 9, 4, 16, 22 and 12 (Table 3). Among these progenies, progeny 9, which also ranks second among the most productive, is worth mentioning.

Horizontal resistance is one of the measures in disease control most sought by researchers, once it is durable and efficient against several races of a certain pathogen. According to Botelho et al. (2010), the intermediate rust incidence of a progeny is important, considering that it is not possible to select progenies with horizontal resistance in progenies that do not show disease incidence, since they probably have vertical or specific resistance, which prevents the manifestation of horizontal resistance.

Del Grossi et al. (2013) evaluated coffee cultivars in the north of Paraná and reported that some cultivars derived from 'Hibrido de Timor' have partial resistance to rust, such as the case of Tupi IAC 1669-33. In the same study, the authors mention other cultivars, also derived from 'Hibrido de Timor', that present complete resistance to rust, such as the cultivars 'Catiguá' MG 1, 'Catiguá' MG 2, IAPAR 59, IPR 98, IPR 104, 'Palma' II, 'Paraíso' H-419-10-6-2-5-1, 'Paraíso' H-41910-6-2-10-1, 'Paraíso' H-419-10-6-2-12-1, 'Pau Brasil' MG 1 and 'Sacramento' MG 1.

Sera et al. (2010) evaluated the rust resistance of twelve new coffee cultivars developed by Instituto Agronômico do Paraná, derived from 'Catuaí' and 'Híbrido de Timor', and concluded that cultivars 'Iapar' 59, IPR 97, IPR 98, IPR 104 and IPR 105 have complete resistance to the local population of rust races present in 'Iapar'. In this study, the authors affirm that cultivars IPR 99, IPR 101, IPR 102 and IPR 107 have about $75 \%$ of plants with complete resistance and probably the resistance gene (s) are in heterozygous condition.

This higher (intermediate) incidence found in the study can be explained by the high yield. One of the factors that increase rust incidence is the high hanging load (CAPUCHO et al., 2009). It is known that coffee rust is highly influenced by the fruit load and the environmental conditions of each year (MEIRA; RODRIGUES; MORAES, 2008, 2009), justifying the existence of the interaction between genotypes and years.

Despite having a higher incidence of the disease, progeny 4 also shows a good plant vigor, and is among the five progenies selected by the rank addition.

Progeny 10 (Icatu V. IAC 2942 x IAC 5002) was the one with the highest disease incidence (Table 4), with yield and percentage of beans in sieve 17 and above below the average of the experiment and a quantity of beans retained in sieve 10 above the average of the experiment. These facts lead to the elimination of this progeny in the breeding continuity of this population.

For disease severity, two groups were identified. In the group with the lower severity, the means were between 1.0 and 1.7, amplitude similar to the results found by Botelho el al. (2010). These authors found values of 0.40 to 1.10 for progenies considered more resistant, values very close to those found in this study. In the group with the highest severity, the means were between 2.0 and 3.67. According to Botelho et al. (2010), the progenies that remained in the intermediate group of disease severity, obtained scores in the same range of the control used in their study, which was cultivar 'Rubi' 1192, with mean severity values of 2.7 , similar to those found in this study.

Of the 25 progenies, 11 were in the group with the lowest disease severity, namely, progenies $19,7,6,11,15,25,20,1,13,21$ and 8 (Table 3 ). In addition to the lower rust severity and incidence, progenies 11 and 13 ranged among the five best selected by the rank addition and progeny 13 also stood out among the most productive progenies. Thus, it was observed in the work that these 11 progenies with the lowest disease severity and incidence, present tolerance to the disease with levels of partial resistance.

In many plants of the Icatu germplasm the resistance was broken, even for the races of Brazil. After breaking, different levels of partial resistance have been frequently detected in the "Icatu" (ESKES et al., 1990).

The selection index was chosen, based on ease of use and interpretation. A ranking was made according to the selection gain of each characteristic for each progeny; this ranking was then summed up, obtaining the rank addition. Thus, the lower the value obtained in the rank addition, the better the progeny performance in relation to the evaluated characteristics. For this study, weight 2 was adopted for the characteristic yield in relation to the other characteristics, since it is of greater interest for genetic breeding.

When analyzed separately, a result of the five best progenies was presented for each characteristic but, when rank addition was made, this result was changed. Of the five best progenies for the characteristic yield, only two were among the best by rank addition, which were progenies 3 and 13 (Table 4); besides yield, these two progenies were also among the five best for the characteristic lower percentage of beans retained in sieve 10 . 
TABLE 4 - Ranking based on the rank addition of 25 coffee progenies, according to te Mulamba-Mock index (1978), in the average of four harvests, evaluated in an experiment in Patrocínio-MG.

\begin{tabular}{ccc}
\hline Ranking & Progenies & Rank addition \\
\hline 1 & 5 & 19 \\
2 & 3 & 20 \\
3 & 4 & 22 \\
4 & 11 & 26 \\
5 & 13 & 29 \\
6 & $24^{*}$ & 35 \\
7 & 8 & 39 \\
8 & 20 & 40 \\
9 & 7 & 41 \\
10 & 1 & 42 \\
11 & 18 & 44 \\
12 & 23 & 45 \\
13 & 17 & 46 \\
14 & 6 & 53 \\
15 & 21 & 53 \\
16 & 2 & 54 \\
17 & 10 & 55 \\
18 & 9 & 55 \\
19 & 16 & 58 \\
20 & 12 & 58 \\
21 & 14 & 59 \\
22 & $25^{*}$ & 60 \\
23 & 22 & 61 \\
24 & 15 & 65 \\
25 & 19 & 65 \\
\hline
\end{tabular}

*Cultivars used as controls.

Regarding plant vigor, three of the five best progenies for this characteristic were among the five best according to the rank addition, which were progenies 5, 4 and 11 (Table 4). Progeny 5, which was the first placed by the rank addition, can be highlighted, showing to be a very interesting genetic material for selection advance, with the best results when all characteristics were analyzed together.

For the characteristic percentage of beans retained in sieve 17 and above and bottom beans, only progeny 11 (first placed for sieve 17 and above and third placed for bottom sieve), was among the five best selected by the rank addition (Table 4). In addition to these characteristics, progeny 11 is among the best classified for plant vigor, occupying the second place for this characteristic.
When analyzing the percentage of beans in sieve 10, it can be observed that four of the five best progenies selected for this characteristic are among the best according to the rank addition, namely, progenies 5, 3, 4 and 13. From these four progenies, two are among the five best for plant vigor, progenies 5 and 4 . The other two progenies, 3 and 13 , are among the five most productive, proving to be interesting for selection advance.

The impact of direct selection in relation to the rank addition for yield had an average difference of $4.59 \%$ of selection gain (Table 5), comparing the five best progenies. The progenies selected directly for this characteristic, compared to control 1 (progenie 24), which obtained the highest mean relative to control 2 (progenie 25) and the global average of the experiment, had a selection gain of $4.93 \%$. 
TABLE 5 - Impact of the direct selection index in comparison with the rank addition for yield in relation to control 1 among the 5 most productive progenies and the first five scored in the rank addition, for coffee progenies in an experiment in Patrocínio, MG.

\begin{tabular}{lllll}
\hline & Progeny & GS Prod/ T1 & Progeny & GS/SP \\
\hline 23 & 7.27 & 5 & 0.35 \\
9 & 6.37 & 3 & 4.36 \\
3 & 4.36 & 4 & 0.67 \\
& 2 & 11 & -6.64 \\
& 13 & 13 & 2.99 \\
\hline Mean & 2.99 & & 0.35 \\
\hline
\end{tabular}

GS Pros/T1: selection gain in yield in relation to control 1;

GS/SP: selection gain in yield in relation to the rank addition.

Special remark is due to progenies 23 and 9 which had a selection gain for yield of " 7.27 " and " 6.37 " respectively. It is known that in genetic improvement it is hard to reach such gains, confirming that it is possible to promote effective increase in the concentration of favourable alels related to the traits studied in the population, and, above all, confirming the potential of these progenies for a leap over generations.

When comparing the progenies that were selected by the rank addition, this gain is $0.35 \%$. This is explained by the fact that, from the progenies that were among the five best by the rank addition, only two were among the five best selected by the direct selection for yield.

\section{CONCLUSIONS}

- Progenies 13 (Icatu V. IAC 4040 x IAC 5002) and 3 (Icatu A. IAC 2944 x IAC 5002) are the most promising for generation advance in the evaluated population, since they combine high yield and resistance to rust

- The selection gain reached by direct selection for the evaluated characteristics is higher than the gain of the total rank addition.

- In the work, progenies derived from Icatu with partial or intermediate resistance to rust were identified.

\section{REFERENCES}

ATROCH, A. L NASCIMENTO FILHO, J. F. do; REZENDE, M.D. V. de, LOPES, R.; CLEMENTE, C. R. Avaliação e seleção de progênies de meios irmãos de guaranazeiro. Revista de Ciências Agrarias, Recife, V 53, n. 2, p, 123-130, jul./dez. 2010.

BOISSEAU, M.; ARIBI, J.; SOUSA, F. R. de; CARNEIRO, R. M. D. G; ANTHONY, F. Resistance to Meloidogyne paranaensis in wild Coffea arabica. Tropical Plant Pathology, Brasília, v. 34, n. 1, p. 38-41, 2009.
BOTELHO, C. E.; MENDES, A. N. G.; CARVALHO, G. R.; BARTHOLO, G. F.; CARVALHO, S. P. Seleção de progênies $\mathrm{F} 4$ de cafeeiros obtidas pelo cruzamento de Icatu com Catimor. Revista Ceres, Viçosa, MG, v. 57, n. 3, p. 274-281, maio/jun. 2010.

CARVALHO, A.; MONÂCO, L. C.; FAZUOLI, L. C. melhoramento do café XL - Estudos de progênies e híbridos de café Catuaí. Bragantia, Campinas, v.38, n.22, p. 202-216, 1979.

CARVALHO, G. R.; BARTHOLO, G. F.; NOGUEIRA, A. M.; BOTELHO, C. E.; PEREIRA, A. A.; CARVALHO, A. M. Comportamento de progênies F4 obtidas por cruzamentos de 'Icatu' com 'Catimor'. Ciência e Agrotecnologia, Lavras, v. 33, n. 1, p. 47-52, jan./fev. 2009.

CARVALHO, A. M.; MENDES, A. N.; BOTELHO, C. E.; OLIVEIRA, A. C. B. de; REZENDE, J. C. de; REZENDE, R. M. Desempenho agronômico de cultivares de café resistentes à ferrugem no estado de Minas Gerais, Brasil. Bragantia, Campinas, v. 71, n. 4, p. $481-487,2012$.

CARVALHO, J. P. F. Seleção de progênies de cafeeiro oriunda da hibridação de cultivares Catuaí com germoplasma Icatú e Hibrido de Timor, 2014, Tese (Doutorado/ Fitotecnia), Universidade Federal de Lavras, 82 p.: il. Lavras - MG.

CAPUCHO A. S.; CAIXETA, E. T.; ZAMBOLIM, E. M.; ZAMBOLIM, L. Herança da resistência do Híbrido de Timor UFV 443-03 à ferrugem-do-cafeeiro. Pesquisa Agropecuaria Brasileira, Brasília, v.44, n.3, p.276-282, mar. 2009.

DEL GROSSI, L.; SERA, G. H.; FONSECA, I. C. de B.; ITO, D. S.; SHIGUEOKA, L. H.; ANDREAZI, E.; CARVALHO, F. G. Rust resistance in arabic coffee cultivars in norther Paraná. Brazilian Archives of Biology and Technology, v.56, p. 27-33, 2013. 
ESKES, A. B.; COSTA, W. M. Characterization of incomplete resistance to Hemileia vastarix in the Icatu coffee population. Euphytica, v.32, p. 649-657, 1983.

ESKES, A. B.; HOOGSTRATEN, J. G. J.; TOMABRAGHINI, M.; CARVALHO, A. Race-specificity and inheritance of incomplete resistance coffee leaf rust in some Icatu coffee offspring and derivatives of Híbrido de Timor. Euphytica, v. 47, p. 11-19, 1990.

FERREIRA, D. F. SISVAR: um programa para analise de estatítica. Revista Symposium, Lavras, v.6, n. 1, p. 36-41, 2008.

FERREIRA, A. D.; CARVALHO. G. R.; REZENDE, J. C.; BOTELHO, C. E.; REZENDE, R. M.; CARVALHO, A. M. Desempenho agronômico de seleções de café Bourbon Vermelho e Bourbon Amarelo de diferentes origens. Pesquisa Agropecuária Brasileira, Brasília, v. 48, n. 4, p. 388-394, abr. 2013.

LAVIOLA, B. G.; MAURI, A. L.; MARTINEZ, H. E. P.; ARAÚJO, E. F.; NEVES, Y. P. Influência da adubação na formação de grãos moca e no tamanho dos grãos de café (Coffea arabica L). Coffee Science, Lavras, v. 1, p. 36-42, abr./jun. 2006.

MATIELLO, J. B. Critérios para escolha de cultivar de café. In: Cultivares de Café: Origem, características e recomendações. Brasília: EMBRAPA Café, 2008, v.1, p. $157-226$.

MEDINA-FILHO, H. P.; BORDIGNON, R.; CARVALHO, C. H. S. Desenvolvimento de novas cultivares de café. In: CARVALHO, C. H. S. Cultivares de café: origem, características e recomendações. Embrapa Café, Brasília, 2008. p. 79102.

MEIRA, C. A. A.; RODRIGUES, L. H. A.; MORAES, S. A. Análise da epidemia da ferrugem do cafeeiro com árvore de decisão. Tropical Plant Pathology, Brasília, v. 33, p. 114-124, 2008.

MEIRA, C. A. A.; RODRIGUES, L. H. A.; MORAES, S. A. Modelos de alerta para o controle da ferrugem-docafeeiro em lavouras com alta carga pendente. Pesquisa Agropecuária Brasileira, Brasília, v. 44, n. 3, p. 233242, mar. 2009.

MULAMBA, N. N.; MOCK, J. J. Improvement of yield potential of the Eto Blanco maize (Zea mays L.) population by breeding for plant traits. Egyptian Journal of Genetics and Cytology, Alexandria, v. 7, n. 1, p. 40-51, 1978.
MUNIZ, M. F. S.; CAMPOS, V. P.; MOITA, A. W.; GONÇALVES, W.; ALMEIDA, M. R. A.; SOUZA, F. R.; CARNEIRO, R. M. D. G. Reaction of coffee genotypes to different populations of Meloidogyne spp.: detection of a naturally virulent $M$. exigua population. Tropical Plant Pathology. vol. 34, n.6 Brasília Nov./ Dec. 2009.

PAIVA, R. N.; CARVALHO, C. H. S.; MENDES, A. N.G.; ALMEIDA, S. R.; MATIELLO, J. B.; FERREIRA, R. A. Field performance of coffee progenies (Coffea arabica L.) in Varginha, Minas Gerais state. Coffee Science. Lavras, v.5, n.1, p. 49-58, jan./abril 2010.

PEREIRA, T. B.; MENDES, A. N. G.; BOTELHO, C. E.; REZENDE, J. C.; VILELA, D. J. M.; RESENDE, M. D. V. Seleção de progênies F4 de cafeeiros obtidas de cultivares do grupo Icatu. Coffee Science, Lavras, v. 8, n. 3, p. 337-346, jul./set. 2013.

PETEK, M. F.; SERA, T.; SERA, G. H.; FONSECA, I. C. B.; ITO, D. S. Seleção de progênies de Coffea arabica com resistência simultânea à mancha aureolada e à ferrugem alaranjada. Bragantia, Campinas, v. 65, n. $1,2006$.

PETEK, M. F.; SERA, T.; FONSECA, I. C. B. de. Exigências Climáticas para o desenvolvimento e maturação dos frutos de cultivares Coffea arabica. Bragantia, Campinas, v. 68, n.1, p. 169-181, 2008.

SANTOS, F. S.; JÚNIOR, A. T. M.; JÚNIOR, S. P. F; RANGEL, R. M.; PEREIRA, M. G. Predição de ganhos genéticos por índice de seleção na população de milhopipoca UNB-2U sob seleção recorrente. Bragantia, Campinas, v. 66, n. 3, p. 389-396, 2007.

SHIGUEOKA, L. H.; SERA, G. H.; SERA, T.; FONSECA, I. C. de B.; MARIUCCI JUNIOR, V.; ANDREAZI, E.; CARVALHO, F. G.; GARDIANO, C. G.; CARDUCCI, F. C. Selection of Arabic coffee progenies with rust resistance. Crop Breeding and Applied Biotechnology, v. 14, p. 88-93, 2014

STATISTICAL ANALYSIS SYSTEM INSTITUTE. SAS/STAT 9.0: user"eguide. Cary, 2009. Software. Disponível em: < http://www.sas.com/pt_br/software/ university-edition.html> Acesso em: 11 de Agosto. 2016

SERA, G. H.; SERA, T.; FONSECA, I. C. B.; ITO, D. S. Resistência à ferrugem alaranjada em cultivares de café. Coffee Science, v.5, p.59-66, 2010. 